\title{
Pengendalian Parameter Suhu Pada Mini Plant Boiler Dengan Menggunakan Pengendali PID
}

\author{
Alexander Christofer Re Gunadhi, Ajat Sudrajat, Kiki Rezki Lestari \\ Program Studi Teknik Fisika, Fakultas Teknik dan Sains, Universitas Nasional \\ Jalan Sawo Manila, Pasar Minggu, 12520 \\ Korespondensi: alexander.christofer.96@gmail.com
}

\begin{abstract}
Abstrak. Boiler adalah suatu peralatan yang dioperasikan agar memproduksi uap air. Sistem boiler terdiri dari sistem air umpan, sistem steam, dan sistem bahan bakar. Salah satu faktor terpenting pada sistem boiler ini adalah suhu, di mana suhu harus dijaga konstan supaya sistem dapat berjalan baik pada saat memproses air menjadi uap. Pada penelitian ini telah dilakukan rancang bangun sistem mini plant boiler dengan sistem berupa loop tertutup (closed loop) dan telah didapatkan nilai parameter PID dengan menggunakan metode Ziegler-Nichols closed loop. Pengujian sistem dilakukan dengan nilai set point suhu $100^{\circ} \mathrm{C}$ dan dilakukan selama \pm 1 jam. Dari pengujian sistem didapatkan nilai respon transien sistem, di antaranya rise time, delay time, settling time, peak time, dan overshoot. Respon sistem menunjukkan bahwa pengendali PID dapat mengendalikan sistem mini plant boiler dengan baik dan mampu mempertahankan nilai set point suhu yang telah ditetapkan.
\end{abstract}

Kata Kunci: Mini Plant Boiler, Pengendalian Suhu, Pengendali PID, Metode ZieglerNichols Closed Loop

\section{PENDAHULUAN}

Sistem pengendalian merupakan hal yang sangat penting pada proses produksi. Agar proses produksi berjalan dengan baik seperti yang diinginkan, maka dibutuhkan sebuah sistem pengendalian. Begitu juga pada boiler diperlukan sebuah sistem pengendalian, karena dalam proses pemanasan sering terjadi kendala sehingga keluaran sistem tidak sesuai dengan yang dikehendaki. Parameter yang menjadi titik fokus sistem boiler adalah suhu. Suhu yang tidak sesuai dengan set point akan menyebabkan banyak masalah seperti terjadinya overheat yang menyebabkan produksi uap tidak sesuai dengan diinginkan. Oleh karena itu, untuk mencapai keadaan ideal diperlukan sistem pengendalian yang sesuai untuk mengendalikan suhu pada boiler $[1,2,3]$. Pada penelitian ini dilakukan rancang bangun pengendalian suhu pada mini boiler dengan menggunakan kendali PID. PID adalah salah satu metode kendali yang memiliki tiga buah parameter, $\mathrm{P}$ (proportional) yang berfungsi untuk memberikan respon sistem, I (integral) yang berfungsi untuk mengkoreksi dan mereduksi offset, dan D (derivatif) yang berfungsi untuk mereduksi overshoot. Ketiga parameter tersebut dapat diaplikasikan menjadi kendali P, PI, PD, dan PID, sesuai dengan kebutuhan. Pengendalian suhu pada mini boiler menggunakan PID dikarenakan suhu adalah salah satu besaran fisis yang memiliki karakteristik respon sistem yang lambat, dan oleh karena itu diperlukan parameter derivatif supaya sistem dapat merespon dengan lebih cepat dan dapat memprediksi keadaan sistem lebih awal [8]. Penelitian ini juga disertakan peningkatan sistem yaitu berupa adanya sistem ESD (Emergency Shut Down) di mana ESD akan bekerja sebagai sistem keamanan mini boiler yang akan mematikan sistem secara otomatis apabila sistem mengalami overheat pada suhu tertentu, mencegah terjadi keretakan boiler dan meledaknya boiler [5].

\section{DASAR TEORI}

\section{Sistem Boiler}

Boiler adalah suatu sistem yang berfungsi untuk mengubah air menjadi uap [3]. Proses perubahan air menjadi uap terjadi dengan memanaskan air yang berada di dalam pipa-pipa 
dengan memanfaatkan panas dari hasil pembakaran bahan bakar. Pembakaran dilakukan secara kontinyu didalam ruang bakar dengan mengalirkan bahan bakar dan udara dari luar. Bagian-bagian dari boiler dan fungsinya antara lain tungku pengapian (Furnace). Bagian ini merupakan tempat terjadinya pembakaran bahan bakar yang akan menjadi sumber panas, proses penerimaan panas oleh media air dilakukan melalui pipa yang telah dialiri air, pipa tersebut menempel pada dinding tungku pembakaran. Bagian berikutnya adalah steam drum. Steam drum berfungsi sebagai tempat penampungan air panas serta tempat terbentuknya uap. Drum ini menampung uap jenuh (saturated steam) beserta air dengan perbandingan antara 50\% air dan 50\% uap. untuk menghindari agar air tidak terbawa oleh uap, maka dipasangi sekat-sekat, air yang memiliki suhu rendah akan turun ke bawah dan air yang bersuhu tinggi akan naik ke atas dan kemudian menguap. Bagian superheater merupakan tempat pengeringan steam, dikarenakan uap yang berasal dari steam drum masih dalam keadaan basah sehingga belum dapat digunakan. Proses pemanasan lanjutan menggunakan superheater pipe yang dipanaskan dengan suhu $260^{\circ} \mathrm{C}$ sampai $350^{\circ} \mathrm{C}$. Dengan suhu tersebut, uap akan menjadi kering dan dapat digunakan untuk menggerakkan turbin maupun untuk keperluan peralatan lain $[3,4]$.

\section{Sistem ESD (Emergency Shut Down) Pada Boiler}

Sistem uap atau boiler adalah sebuah alat yang digunakan untuk memproduksi steam. Suhu pada boiler sangat tinggi sehingga tekanannya juga tinggi. Oleh sebab itu, sistem uap perlu dijaga keamanannya. Salah satu metode penanganan keamanan pada boiler adalah dengan adanya sistem ESD (Emergency Shut Down). Sistem ESD ini bekerja mematikan sistem boiler dan diperlukan apabila terjadi hal-hal yang bersifat urgent dan berbahaya pada boiler, seperti overheat dan overpressure yang dapat mengakibatkan kerusakan dan meledaknya boiler. Salah satu jenis perangkat keamanan otomatis yang sangat dibutuhkan pada sistem ESD pada boiler adalah safety valve atau shutdown valve. Safety valve akan melindungi alat dan perangkat dari bahaya yang diakibatkan oleh suhu dan tekanan uap berlebih dalam sistem. Sedangkan shutdown valve akan mematikan supply gas burner apabila terjadi overpressure dan overheat pada sistem boiler, sehingga sistem tidak melakukan pembakaran lagi [5].

Prinsip kerja dari safety valve adalah sebagai berikut: safety valve akan membuka dan membuang steam yang berlebih apabila suhu dan tekanan di dalam sistem uap melampaui batas set point. Sedangkan untuk prinsip kerja dari shutdown valve adalah sebagai berikut: shutdown valve akan menutup aliran gas yang digunakan untuk pembakaran saat sistem boiler berjalan apabila suhu dan tekanan melampaui batas set point dan batas emergency HH (high-high), sehingga pembakaran akan terhenti. Safety valve dan shutdown valve harus ditinjau ulang secara periodik tergantung standar unit, rekomendasi jaminan perusahaan, dan hukum pemerintah. The American Society of Mechanical Engineers (ASME) merupakan departemen yang mengatur mengenai safety valve. [5]

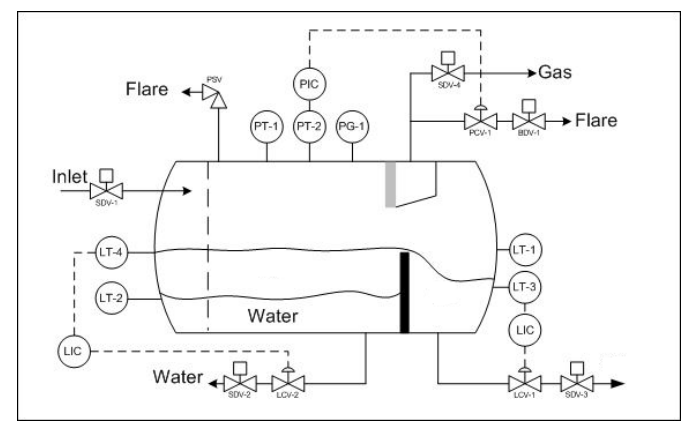

Gambar 2. Sistem Safety Boiler [5].

\section{Pengendali PID (Proportional-Integral-Derivatif)}

Kontrol automatik dalam dunia pengendalian terdiri dari tiga macam, yaitu kontrol $\mathrm{P}$ (Proportional) yang berfungsi untuk mempercepat respon, kontrol I (Integral) yang berfungsi untuk mengkoreksi dan mereduksi offset, dan kontrol D (Derivatif) yang 
berfungsi untuk memprediksi dan mereduksi overshoot. Ketiga kontrol ini sebenarnya dapat diaplikasikan menjadi kontrol P (Proportional), kontrol PI (Proportional-Integral), kontrol PD (Proportional-Derivatif), dan kontrol PID (Proportional-Integral-Derivatif) [1]. Kontrol PID secara matematis dirumuskan sebagai berikut [6]:

$$
\mathrm{M}(\mathrm{t})=\mathrm{Kp}\left[\mathrm{e}(\mathrm{t})+\frac{1}{\mathrm{Ti}} \int e(t) \mathrm{dt}+\mathrm{Td} \frac{\mathrm{de}(\mathrm{t})}{\mathrm{dt}}\right]
$$

Atau dapat juga dituliskan dengan:

$$
M(t)=(K p e(t))+\left(K i \int e(d t)\right)+\left(K d \frac{d e(t)}{d t}\right)
$$

Dengan nilai Ki dan Kd pada persamaan (2) didapat dari:

$$
\begin{aligned}
& \mathrm{Ki}=\mathrm{Kp} \frac{1}{\mathrm{Ti}} \\
& \mathrm{Kd}=\mathrm{Kp} \mathrm{Td}
\end{aligned}
$$

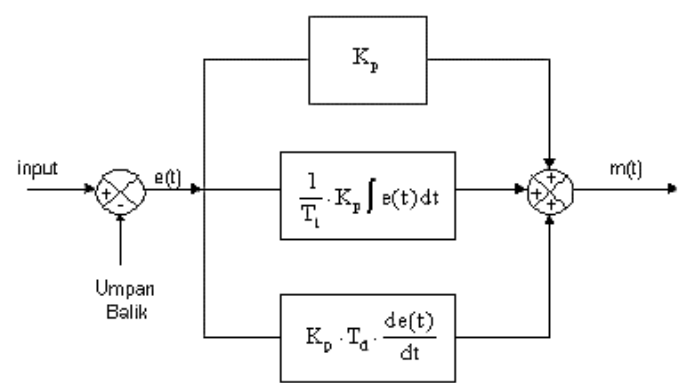

Gambar 3. Blok Diagram Kontrol PID [6]

\section{Pengendalian Feedback Control}

Feedback control adalah suatu metode pengendalian di mana pengendalian pada sistem dilakukan dengan mengembalikan kembali (mengumpan balik) nilai proses sistem jika terjadi perbedaan antara nilai output dengan nilai input atau set point. Feedback control merupakan salah satu metode pengendalian loop tertutup atau closed loop. Perbedaan antara nilai output dengan nilai input atau set point disebut dengan error. Error dapat terjadi akibat adanya gangguan (disturbance) yang berasal dari luar. Dengan adanya sistem feedback ini, maka error ini dapat diminimalisir saat proses pada sistem berjalan. Komponen yang umumnya menerima dan mengembalikan feedback untuk dikoreksi kembali adalah sensor. Sensor membaca keluaran plant dan apabila ditemukan ketidaksesuaian antara input dengan output plant, maka sensor akan mengumpan balik keluaran plant untuk dikoreksi kembali [6].

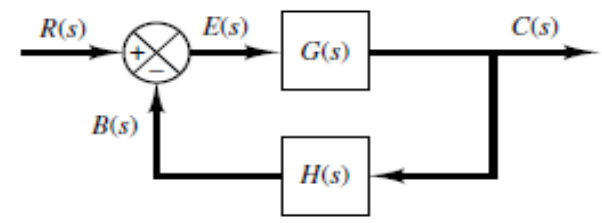

Gambar 4. Pengendalian Feedback Control [6].

\section{Penentuan Nilai Parameter PID}

Untuk menentukan nilai parameter PID yang dipergunakan, dapat dipergunakan metode menggunakan perhitungan fungsi transfer sistem $[6,7,9]$ :

- Membuat blok diagram sistem yang akan dibuat terlebih dahulu, di mana terdapat input, blok summing, blok kontroler, blok aktuator, blok plant, blok sensor, dan output.

- Mencari nilai spesifikasi input dan output tiap alat yang digunakan sebagai aktuator dan sensor. Lalu mencari nilai gain tiap alat dengan menggunakan rumus: 


$$
\mathrm{G}=\frac{\Delta \mathrm{O}}{\Delta \mathrm{I}}
$$

- Menghitung fungsi transfer untuk blok aktuator, blok plant, dan blok sensor dengan menggunakan rumus fungsi transfer orde satu (kecuali kontroler dimisalkan K):

$$
\mathrm{FT}=\frac{\mathrm{G}}{\tau s+1}
$$

- Menghitung fungsi transfer untuk seluruh sistem dengan menggunakan rumus fungsi transfer total sistem, di mana pada blok atas dimisalkan $\mathrm{G}_{\mathrm{s}}$ dan pada blok bawah dimisalkan $\mathrm{H}_{\mathrm{s}}$ :

$$
\mathrm{FT}_{\mathrm{s}}=\frac{\mathrm{G}_{\mathrm{s}}}{1+\mathrm{G}_{\mathrm{s}} \mathrm{H}_{\mathrm{s}}}
$$

- Mencari nilai rentang K pada kontroler berdasarkan persamaan fungsi transfer total sistem yang didapatkan dengan metode Routh Hurwitz, di mana pada metode Routh Hurwitz mempergunakan denominator atau penyebut persamaan fungsi transfer total sistem untuk mencari nilai rentang $\mathrm{K}$ kontroler.

$$
\mathrm{FT}_{\mathrm{s}}=\frac{\operatorname{num}(\mathrm{s})}{\operatorname{den}(\mathrm{s})}
$$

- Menggunakan batas atas rentang $\mathrm{K}$ yang telah didapatkan sebagai nilai Kcr (Critical Gain) yang diharapkan dapat membuat sistem berosilasi maksimum dan berkelanjutan (sustain oscillation). Pada bagian ini dimulailah dilakukannya tuning kontroler dengan metode Ziegler Nichols closed loop (loop tertutup). Nilai Kcr tadi dimasukkan ke dalam kontroler, pada parameter P. Sedangkan parameter I dan D diberi angka 0.

- Menemukan nilai Pcr (Critical Period) di mana nilai ini dapat ditemukan setelah respon sistem berosilasi sustain oscillation, jika syarat tersebut sudah terpenuhi maka dilakukan perhitungan Pcr dengan mencari dua nilai t pada dua buah puncak yang memiliki amplitudo tertinggi dan menghitung selisihnya, sehingga didapatkan nilai Pcr.

- Mencari dan menghitung nilai parameter yang dibutuhkan untuk pengendalian (P atau PI atau PID dengan menggunakan nilai Kcr dan Pcr yang didapat dan dimasukkan ke dalam tabel tuning Ziegler-Nichols.

\section{Tuning Ziegler-Nichols}

Ziegler-Nichols pertama kali memperkenalkan metode tuning kontroler-nya pada tahun 1942. Metode ini didasarkan pada reaksi sistem loop tertutup (closed loop). Plant disusun seri dengan pengendali PID. Semula parameter integrator (I) diset tak hingga (atau tak hingga diset 0 ) dan parameter derivator (D) diset 0 . Lalu untuk parameter proportional (P) diset sesuai nilai gain yang mampu membuat sistem berosilasi dengan magnitudo tetap (sustain oscillation). Nilai penguatan proportional pada saat sistem mencapai kondisi sustain oscillation disebut Kcr (critical gain). Periode yang didapat dari sustained oscillation disebut Pcr (ultimate period). Penalaan parameter PID didasarkan terhadap kedua konstanta hasil eksperimen, yaitu Kcr dan Pcr. Tuning Ziegler-Nichols menyarankan penyetelan nilai parameter $\mathrm{Kp}(\mathrm{P}), \mathrm{Ti}(\mathrm{I})$, dan $\mathrm{Td}(\mathrm{D})$ berdasarkan rumus [6]:

Tabel 1. Tabel Tuning Kontroler Ziegler-Nichols [6].

\begin{tabular}{|c|c|c|c|}
\hline Tipe Kontroler & $\mathrm{Kp}$ & $\mathrm{Ti}$ & $\mathrm{Td}$ \\
\hline $\mathrm{P}$ & $0,5 \mathrm{Kcr}$ & $\sim$ & 0 \\
\hline $\mathrm{PI}$ & $0,45 \mathrm{Kcr}$ & $\frac{1}{1,2} \mathrm{Pcr}$ & 0 \\
\hline $\mathrm{PID}$ & $0,6 \mathrm{Kcr}$ & $0,5 \mathrm{Pcr}$ & $0,125 \mathrm{Pcr}$ \\
\hline
\end{tabular}

\section{Respon Transien}

Respon sistem dibagi menjadi 2 macam, yaitu respon transien dan respon steady state. Respon transien adalah respon saat sistem masih berosilasi hingga mencapai keadaan stabil (tunak), sedangkan respon steady state adalah respon saat sistem sudah mencapai keadaan stabil (tunak) nya. Karakteristik suatu sistem kendali biasanya dilihat dari respon transien 
yang dimilikinya. Untuk menganalisis sistem kendali, biasanya dipergunakan input step karena input step menyediakan informasi tentang karakteristik respon transien dari suatu sistem, seperti Rise time, Delay time, Settling time, Peak time, Overshoot [6].

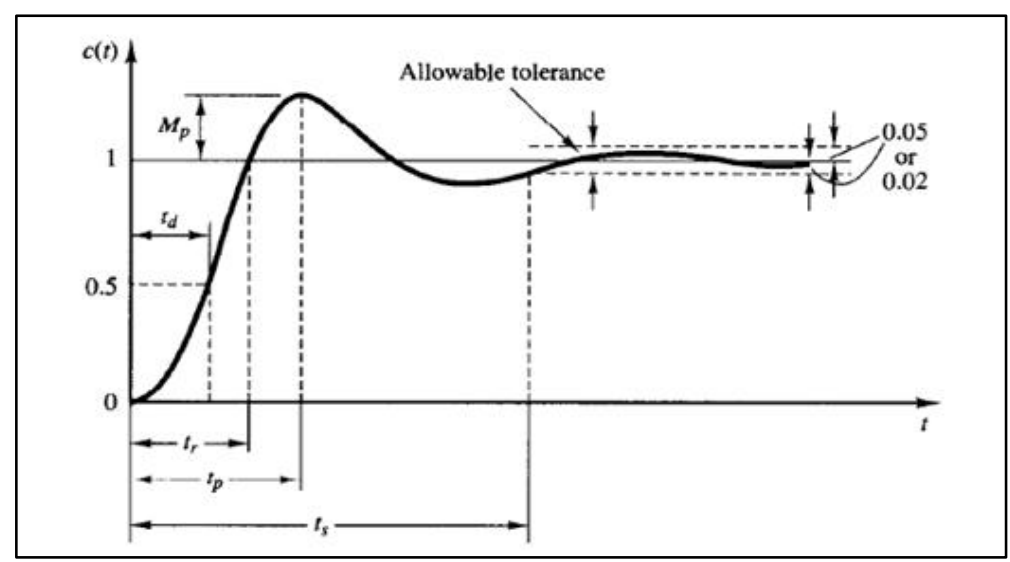

Gambar 6. Respon Transien Sistem [6].

\section{METODE PENELITIAN}

\section{Pemodelan Sistem.}

Pemodelan sistem dilakukan di MATLAB, di dalam Simulink. Pemodelan sistem dilakukan untuk membuat simulasi sistem dan mencari nilai PID yang dibutuhkan.

Perhitungan Matematis.

Pada bagian perhitungan matematis, akan digunakan perhitungan menggunakan fungsi transfer sistem dengan metode Ziegler-Nichols closed loop untuk menghitung persamaan fungsi transfer tiap blok, fungsi transfer sistem, dan untuk mencari nilai PID yang digunakan. Digunakannya fungsi transfer untuk perhitungan matematis sistem dikarenakan sistem yang dibuat adalah sistem SISO (single input - single output) yang dapat mempergunakan fungsi transfer untuk perhitungannya.

\section{Rancang Bangun Sistem.}

Rancang bangun sistem dilakukan setelah mempersiapkan alat-alat yang dibutuhkan. Sistem yang dibuat akan digunakan untuk pengambilan data.

\section{Pengujian Sistem.}

Setelah perancangan sistem selesai, sistem akan diuji dahulu untuk memastikan semua komponen mekanikal dan elektrikal dapat berjalan dengan baik. Jika sudah dapat berjalan, selanjutnya dilakukan dengan pengambilan data. Pengujian sistem ESD dilakukan dengan cara memberikan nilai set point $\mathrm{HH}$ (High-High) kepada kontroler, di mana nanti kontroler akan memerintahkan sistem ESD untuk mematikan sistem berdasarkan set point $\mathrm{HH}$ (HighHigh) tersebut. Pengujian ini dilakukan untuk mengetahui apakah sistem ESD bekerja saat sistem mencapai set point HH pada keadaan emergency. Hal ini dilakukan sebelum pengambilan data supaya sistem memiliki sistem safety terlebih dahulu.

\section{Pengolahan Data Pengujian.}

Untuk pengambilan data, dilakukan selama kurang lebih setengah atau satu jam dengan menggunakan serial monitor Arduino Uno, lalu data dipindahkan ke dalam Microsoft Excel 2016 untuk diplot dalam grafik.

Pengolahan data yang dilakukan pada data pengujian adalah pengolahan data nilai overshoot, offset, rise time, delay time, peak time, dan settling time, berdasarkan rumus yang terdapat pada studi literatur.

\section{Analisis Hasil Pengujian.}

Analisis yang dilakukan pada data pengujian adalah analisis nilai overshoot, offset, rise time, delay time, peak time, dan settling time, berdasarkan grafik yang telah diplot di dalam Microsoft Excel 2016. 


\section{Simulasi Sistem.}

Blok diagram yang telah dibuat sebelumnya, disimulasikan kembali pada simulink MATLAB R2016a, dengan memasukkan setiap blok dengan fungsi transfer masingmasing dan nilai PID dengan nilai yang didapatkan dari perhitungan Ziegler-Nichols.

\section{Analisis Hasil Simulasi.}

Analisis yang dilakukan pada data simulasi sama dengan analisis data pengujian, antara lain adalah analisis nilai overshoot, offset, rise time, delay time, peak time, dan settling time, berdasarkan simulink atau command window pada MATLAB R2016a.

\section{Analisis Data Simulasi.}

Analisis yang dilakukan pada data simulasi sama dengan analisis data pengujian, antara lain adalah analisis nilai overshoot, offset, rise time, delay time, peak time, dan settling time, berdasarkan simulink atau command window pada MATLAB R2016a.

\section{HASIL DAN PEMBAHASAN}

Hasil Rancang Bangun Mini Boiler.

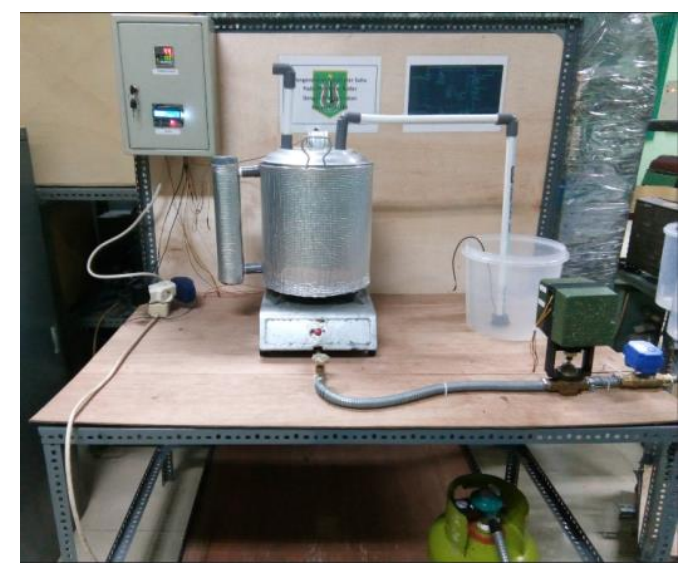

Gambar 7. Hasil Racang Bangun Mini Boiler.

Gambar 7 adalah hasil rancang bangun mini plant boiler yang dibuat di Laboratorium Teknik Fisika, Universitas Nasional. Sistem terdiri dari sistem elektrikal, sistem pemanas, sistem boiler, sistem tangki umpan, sistem aktuator, dan sistem safety.

Sistem elektrikal mini plant boiler terdapat di dalam panel yang terletak di sebelah kiri atas. Panel tersebut berisi kontroler suhu Autonics TCN4S-24R untuk mengendalikan suhu mini boiler, trafo step down $220 \mathrm{VAC}-24 \mathrm{VAC}$ untuk supply power control valve yang mengatur aliran gas LPG, Arduino Uno untuk kontroler pompa, sensor ultrasonik, dan LCD $16 \times 2$, serta projectboard sebagai terminal gabungan seluruh kabel positif dan negatif. Sistem pemanas mini plant boiler terdiri dari tabung gas LPG $3 \mathrm{~kg}$, regulator Quantum, dan selang yang menuju ke burner, yang akan menyuplai gas dan memunculkan api untuk memanaskan sistem mini boiler.

Sistem boiler terdiri dari tangki boiler yang menggunakan bahan alumunium berdiameter $7,5 \mathrm{~cm}$ dan tinggi $30 \mathrm{~cm}$, dengan lubang pengeluaran uap dan lubang pemasukan air cadangan dari tangki umpan. Sistem boiler dilengkapi dengan sensor ultrasonik yang berfungsi membaca ketinggian air di dalam boiler selama proses berjalan, dan ditampilkan pada indikator berupa LCD 16x2. Pembacaan suhu di dalam boiler menggunakan sensor suhu PT100 yang di mana bacaannya dapat kita lihat pada kontroler Autonics TCN4S-24R. Sistem tangki umpan terdiri dari satu buah tangki berisi air cadangan, yang akan di-supply ke dalam tangki boiler secara otomatis oleh pompa DC, apabila ketinggian tangki boiler berada pada ketinggian di bawah $10 \mathrm{~cm}$. Dan ketika ketinggian air sudah sama dengan 10 $\mathrm{cm}$ atau di atas $10 \mathrm{~cm}$, maka pompa DC akan otomatis mati. 
Sistem aktuator terdiri dari control valve Controlli MVB56 yang berbentuk globe valve, memerlukan power supply $24 \mathrm{VAC}$, dan mempunyai sinyal kontrol masukan 4-20 mA dan keluaran $0-100 \%$. Control valve inilah yang mengatur besar-kecilnya supply gas dari tabung LPG menuju burner. Besar-kecilnya buka-tutup valve ini bergantung dengan suhu yang terbaca pada sensor dan perintah dari kontroler suhu.

Sistem safety terdiri dari motorized valve CWX 3 wires yang berbentuk ball valve, memerlukan power supply 12 VDC, bersifat fail close, dan hanya mempunyai sinyal onoff saja, sehingga sesuai dan dapat digunakan sebagai pengaman sistem apabila terjadi malfungsi. Saat terjadi malfungsi, valve ini akan menutup rapat gas yang melewati selang dan mematikan sistem.

\section{Hasil Perhitungan Matematis.}

Setelah dilakukan perhitungan matematis dengan menggunakan metode Ziegler-Nichols closed loop, dengan nilai $\mathrm{Kcr}=8$ dan $\mathrm{Pcr}=3.6$ maka didapatkan nilai PID untuk pengendalian seperti pada tabel 2 .

Tabel 2. Hasil Perhitungan PID

\begin{tabular}{|c|c|c|c|}
\hline Tipe Kontroler & $\mathrm{Kp}$ & $\mathrm{Ti}$ & $\mathrm{Td}$ \\
\hline $\mathrm{P}$ & $0,5 \mathrm{Kcr}$ & $\sim$ & 0 \\
\hline PI & $0,45 \mathrm{Kcr}$ & $\frac{1}{1,2} \mathrm{Pcr}$ & 0 \\
\hline PID & $\begin{aligned} 0,6 \mathrm{Kcr} & =0,6 \times 8 \\
& =4,8\end{aligned}$ & $\begin{aligned} 0,5 \text { Pcr } & =0,5 \times 3,6 \\
& =1,8\end{aligned}$ & $\begin{aligned} 0,125 \mathrm{Pcr} & =0,125 \times 3,6 \\
& =0,45\end{aligned}$ \\
\hline
\end{tabular}

Nilai PID ini dimasukkan ke dalam simulasi MATLAB saat simulasi dan dimasukkan juga ke dalam kontroler saat pengujian sistem untuk mendapatkan respon sistemnya.

\section{Hasil Pengujian Sistem ESD.}

Pengujian sistem ESD (Emergency Shut Down) dilakukan dengan mencoba memberikan input set point $\mathrm{HH}$ (High-High) pada suhu $100^{\circ} \mathrm{C}$, saat air mendidih. Hal ini dilakukan untuk mengetahui apakah sistem ESD berjalan atau tidak saat mencapai set point tersebut. Dan saat dilakukan pengujian, sistem ESD berhasil melakukan shutdown system saat mencapai set point percobaan tersebut.

Selanjutnya, untuk nilai set point $\mathrm{HH}$ pada sistem mini boiler ditetapkan permanen pada suhu $110^{\circ} \mathrm{C}$. Hal ini dikarenakan apabila pemanasan sistem diteruskan hingga suhu makin tinggi, dikhawatirkan sistem mini boiler akan mengalami kerusakan, seperti retak, pecah, bahkan meledak.

Dan selama dilakukan 3 kali pengambilan data, suhu tertinggi berada pada $102^{\circ} \mathrm{C}$, dan tidak pernah mencapai set point $\mathrm{HH}$. Oleh karena itu, sistem ESD tidak menyala saat dilakukan pengambilan data. Namun, apabila nilai PID yang dimasukkan berbeda, tidak menutup kemungkinan sistem dapat mencapai suhu $\mathrm{HH}$ yang ditetapkan, sehingga sistem akan shut down secara otomatis, karena nilai PID yang dimasukkan dapat mempengaruhi respon sistem.

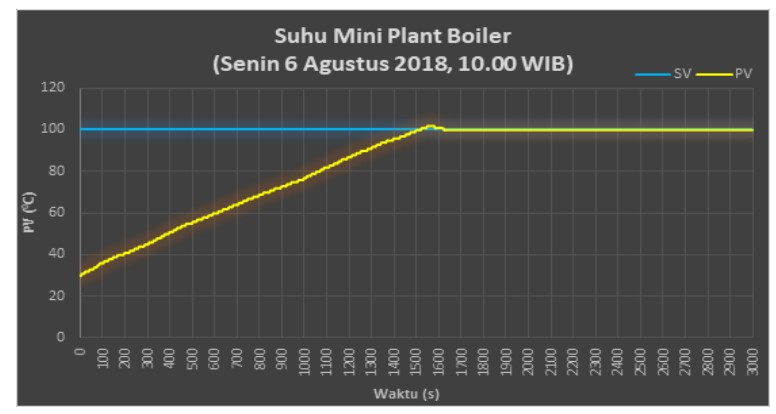

Gambar 8. Suhu Mini Plant Boiler Hari Pertama 


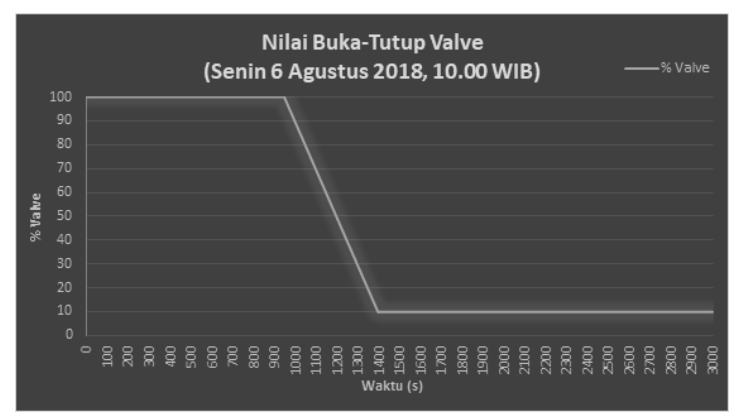

Gambar 9. Nilai Buka-Tutup Valve Hari Pertama

Gambar 8 dan 9 adalah data uji sistem mini boiler diuji dan dilakukan pengambilan data pertama suhu mini boiler dan data buka-tutup valve selama \pm 1 jam. Untuk data suhu mini boiler, pengambilan data dilakukan mulai dari suhu awal (suhu terendah mini boiler yang setara dengan suhu ruangan tempat pengujian) yaitu $30^{\circ} \mathrm{C}$ hingga suhu akhir (suhu yang ditetapkan sebagai set point dan sistem dalam keadaan steady state) yaitu $100^{\circ} \mathrm{C}$. Saat proses berjalan, terlihat bahwa sistem mengalami kenaikan yang lambat dalam fasa transien, namun dapat mempertahankan keadaan steady dalam fasa steady state.

Untuk data buka-tutup valve, pengambilan data dilakukan dengan merekam keadaan bukatutup valve berdasarkan sinyal valve. Untuk keadaan awal, keadaan di mana sistem mulai berjalan, valve memiliki bukaan $100 \%$ (bukaan penuh). Seiring berjalannya waktu dan meningkatnya suhu mini boiler, valve mulai mengurangi persentase bukaannya dan mulai mengecilkan bukaannya secara perlahan, hingga pada akhirnya valve hanya membuka dengan bukaan yang cukup kecil, yaitu hanya 10\% (bukaan hampir menutup) saat sistemmulai mencapai set point.

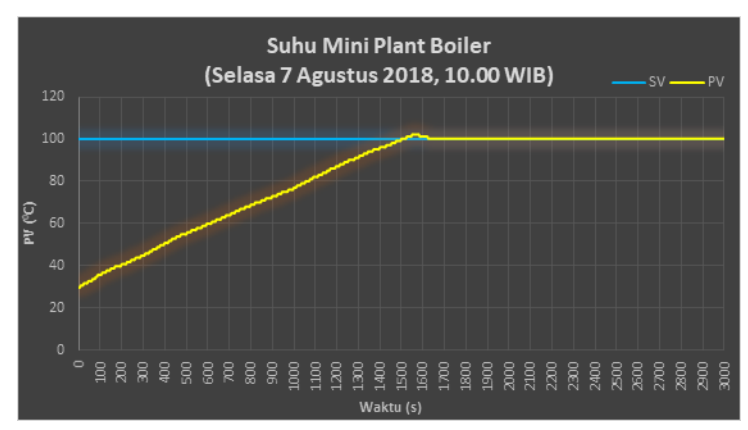

Gambar 10. Suhu Mini Plant Boiler Hari Kedua

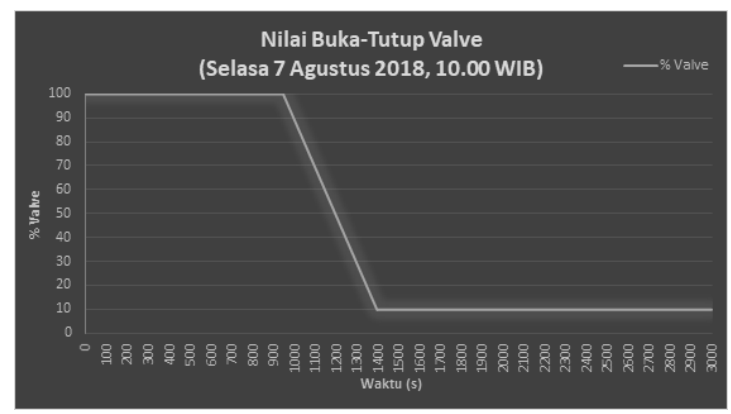

Gambar 11. Nilai Buka-Tutup Valve Hari Kedua

Gambar 10 dan 11 adalah data sistem mini boiler diuji kembali dan dilakukan pengambilan data kedua suhu mini boiler dan data buka-tutup valve selama \pm 1 jam. Dan hasil yang didapatkan pada hari kedua ini tidak jauh berbeda dengan hari pertama.

Untuk data suhu mini boiler, pengambilan data dilakukan mulai dari suhu awal (suhu terendah mini boiler yang setara dengan suhu ruangan tempat pengujian) yaitu $30^{\circ} \mathrm{C}$ hingga suhu akhir (suhu yang ditetapkan sebagai set point dan sistem dalam keadaan steady state) yaitu $100^{\circ} \mathrm{C}$. Saat proses berjalan, terlihat bahwa sistem mengalami kenaikan yang lambat dalam fasa transien, namun dapat mempertahankan keadaan steady dalam fasa steady state. 
Untuk data buka-tutup valve, pengambilan data dilakukan dengan merekam keadaan bukatutup valve berdasarkan sinyal valve. Untuk keadaan awal, keadaan di mana sistem mulai berjalan, valve memiliki bukaan $100 \%$ (bukaan penuh). Seiring berjalannya waktu dan meningkatnya suhu mini boiler, valve mulai mengurangi persentase bukaannya dan mulai mengecilkan bukaannya secara perlahan, hingga pada akhirnya valve hanya membuka dengan bukaan yang cukup kecil, yaitu hanya 10\% (bukaan hampir menutup) saat sistem mulai mencapai set point.

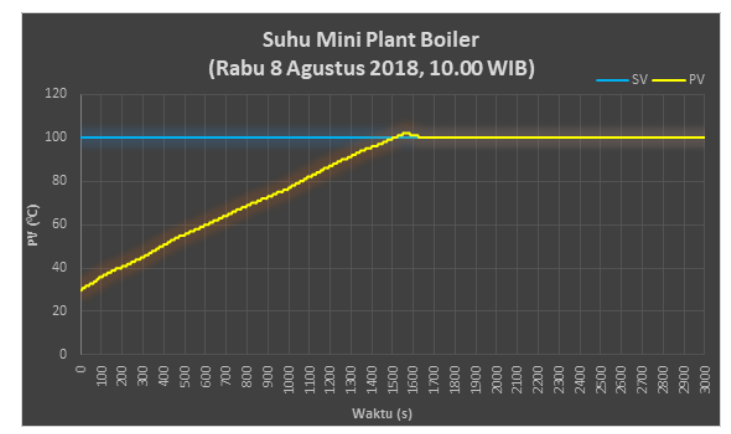

Gambar 12. Suhu Mini Plant Boiler Hari Ketiga

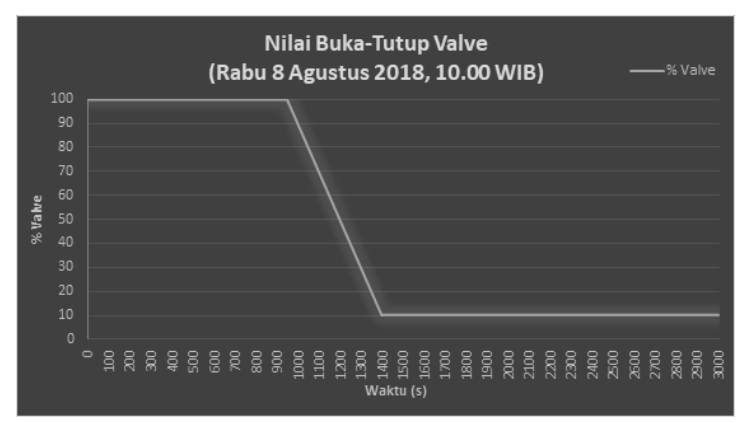

Gambar 13. Nilai Buka-Tutup Valve Hari Ketiga

Gambara 12 dan 13 adalah pengambilan data ketiga suhu mini boiler dan data buka-tutup valve selama \pm 1 jam. Dan hasil yang didapatkan pada hari ketiga pun tidak jauh berbeda dengan hari pertama dan kedua.

Untuk data suhu mini boiler, pengambilan data dilakukan mulai dari suhu awal (suhu terendah mini boiler yang setara dengan suhu ruangan tempat pengujian) yaitu $30^{\circ} \mathrm{C}$ hingga suhu akhir (suhu yang ditetapkan sebagai set point dan sistem dalam keadaan steady state) yaitu $100^{\circ} \mathrm{C}$. Saat proses berjalan, terlihat bahwa sistem mengalami kenaikan yang lambat dalam fasa transien, namun dapat mempertahankan keadaan steady dalam fasa steady state. Untuk data buka-tutup valve, pengambilan data dilakukan dengan merekam keadaan bukatutup valve berdasarkan sinyal valve. Untuk keadaan awal, keadaan di mana sistem mulai berjalan, valve memiliki bukaan $100 \%$ (bukaan penuh). Seiring berjalannya waktu dan meningkatnya suhu mini boiler, valve mulai mengurangi persentase bukaannya dan mulai mengecilkan bukaannya secara perlahan, hingga pada akhirnya valve hanya membuka dengan bukaan yang cukup kecil, yaitu hanya 10\% (bukaan hampir menutup) saat sistem mulai mencapai set point. Dari hasil pengujian yang dilakukan langsung pada sistem sebanyak tiga kali dan telah dirata-rata, maka dapat kita analisis hasil respon sistemnya sebagai berikut:

Tabel 3. Analisis Hasil Pengujian

\begin{tabular}{|c|l|c|}
\hline No. & \multicolumn{1}{|c|}{ Parameter Analisis } & Hasil \\
\hline 1. & Rise time (tr) & $1.462,5 \mathrm{~s}$ \\
\hline 2. & Delay time (td) & $812,5 \mathrm{~s}$ \\
\hline 3. & Settling time $(\mathrm{ts})$ & $1.706,25 \mathrm{~s}$ \\
\hline 4. & Peak time $(\mathrm{tp})$ & $1.550 \mathrm{~s}$ \\
\hline 5. & Overshoot & $2 \%$ \\
\hline
\end{tabular}


Dari ketiga hasil pengujian yang dilakukan pada hari yang berbeda pula, didapatkan hasil pengujian yang tidak jauh berbeda. Diperoleh nilai rise time sebesar 1.462,5 sekon, delay time sebesar 812,5 sekon, settling time sebesar 1.706,25 sekon, peak time sebesar 1.550 sekon, dan overshoot sebesar $2 \%$. Sistem memiliki respon yang lambat untuk mencapai nilai steady state-nya dikarenakan pengendalian besaran fisis untuk suhu memang tergolong lambat dibandingkan dengan besaran fisis lain seperti tekanan (pressure), ketinggian (level), atau aliran (flow). Dibutuhkan waktu sekitar 25 hingga 30 menit untuk sistem memulai respon dari awal hingga mencapai nilai steady-nya. Selain dikarenakan sifat besaran suhu yang memiliki respon lambat, hal ini juga bisa disebabkan oleh faktor lingkungan di mana pengujian sistem mini plant boiler dilakukan. Namun, sistem berhasil mempertahankan nilai PV (process variable) sesuai nilai SV (set variable) yang telah ditentukan, yaitu $100^{\circ} \mathrm{C}$.

\section{Hasil Simulasi Sistem.}

Dari ketiga simulasi yang dilakukan, didapatkan hasil respon sistem yang sama, dikarenakan simulasi memiliki function block yang sama dan simulasi yang dilakukan pun terkondisi, dalam arti tidak dipengaruhi oleh keadaan lingkungan sistem. Diperoleh nilai rise time sebesar 1.100 sekon, delay time sebesar 550 sekon, settling time sebesar 1.800 sekon, peak time sebesar 1.750 sekon, dan overshoot sebesar $0 \%$. Respon sistem yang muncul pun memiliki respon transien dan steady state yang bagus. Seperti dirangkum pada table 4.

Tabel 4. Analisis Hasil Simulasi

\begin{tabular}{|c|l|c|}
\hline No. & \multicolumn{1}{|c|}{ Parameter Analisis } & Hasil \\
\hline 1. & Rise time (tr) & $1.100 \mathrm{~s}$ \\
\hline 2. & Delay time (td) & $550 \mathrm{~s}$ \\
\hline 3. & Settling time (ts) & $1.800 \mathrm{~s}$ \\
4. & Peak time (tp) & $1.750 \mathrm{~s}$ \\
\hline 5. & Overshoot & $0 \%$ \\
\hline
\end{tabular}

Hal ini ditunjukkan dengan respon sistem yang naik dari keadaan awal hingga menyentuh set point hanya membutuhkan waktu 1.100 sekon yang bisa dikatakan tidak terlalu lama, dan pada saat mencapai set point, sistem tidak memiliki overshoot sama sekali. Selain itu, sistem mampu mempertahankan keadaan steady state pada set point yang telah ditentukan dalam jangka waktu yang lama. Dengan demikian, nilai tuning PID yang telah didapatkan adalah benar, karena hasil yang diharapkan saat penentuan nilai P, I, dan D melalui tuning adalah didapatkannya respon sistem yang bisa mencapai keadaan steady state.

\section{KESIMPULAN}

Kesimpulan yang didapatkan dari penelitian mini plant boiler ini adalah sistem telah berhasil mengendalikan mini plant boiler yang harus mempunyai suhu sebesar 1000C saat beroperasi. Nilai PID yang didapatkan dengan metode Ziegler-Nichols Closed Loop mampu mengendalikan mini plant boiler sesuai dengan nilai set point yaitu 1000C. Grafik respon pengujian telah mewakili keadaan aktual respon sistem saat pengujian sesungguhnya. Grafik ini lah yang mewakili bagaimana respon besaran suhu pada suatu sistem, di mana pengendalian suhu memiliki karakteristik lambat saat mulai bereaksi hingga mencapai nilai steady state. Sistem ESD (Emergency Shut Down) mini plant boiler telah berhasil melakukan shutdown system saat diuji dengan nilai set point suhu tertentu.

\section{DAFTAR PUSTAKA}

[1] Esti Lusi Purwati, "Perancangan Kendali PI Untuk Parameter Level Dan Temperatur Pada Boiler", Tugas Akhir, Universitas Nasional, Jakarta, 2016. 
[2] Ridwan Yunus, V Vekky R Repi, Fitria Hidayanti, "Perancangan Sistem Kontrol on/off Multivariabel Level dan Temperatur berbasis mikrokontroler", Jurnal Ilmiah Giga, Volume 19, No. 1 (2016).

[3] Reynaldo Sandy Montolalu, "Rancang Bangun Sistem Kontrol Level Dan Temperatur Boiler Dengan Metode PID Dan Kontrol Dua Posisi", Telkom University, Bandung, 2015.

[4] Zulfa Anis Labiba, "Rancang Bangun Sistem Monitoring Temperatur Steam Output Terintegrasi HMI Pada Mini Plant Boiler Di Workshop Instrumentasi", Institut Teknologi Sepuluh November, Surabaya, 2017.

[5] Karjono, Boiler Uap Dan Sistem Tenaga Uap, Jakarta: Pusdiklat Migas, 2002.

[6] Bromindo, Safety Valve, Shutdown Valve, Dan Sistem Safety Pada Boiler, Jakarta: Mekar Mitra, 2018.

[7] Katshuhiko Ogata, Modern Control Engineering (5th Edition), USA: Prentice Hall, 2010.

[8] Bakti Yudho, "Aplikasi Perbandingan P, PI, Dan PID Pada Proses Pengendalian Mini Boiler”, Universitas Sriwijaya, Palembang, 2013. 